\title{
Contemporary Vietnam Economy Present Situation and Development Trend
}

\author{
Tran Mai Uoc \\ Banking University of Ho Chi Minh City
}

\begin{abstract}
Human development is one of the most important goals of development. Under the impact of socio-economic conditions and the practical needs, the issue of human development is conceived more and more completely, comprehensively and deeply in the current period. The article analyzes and clarifies the basic issues related to human construction and development in Vietnam today.
\end{abstract}

Keywords: Human; human development; human liberation; practices

\section{Introduction}

In the current context, the position, role, goals, contents and methods of solving human construction and development problems are conceived increasingly completely, comprehensively and deeply. This, in essence, is suitable to the development trend and is of objective inevitability. Human liberation and comprehensive Vietnamese people care, construction and development are the Party's uniform and consistent goal which is expressed throughout the congresses and in all guidelines and policies of the Party and State.

\section{Contents}

2.1 Human construction and development from viewpoints of Party congresses

At the $7^{\text {th }}$ National Party Congress (1991), in the "Platform for country construction during transition to socialism", our Party affirmed: "promoting the human factor is on the basis of ensuring fairness and equality in citizens' rights and obligations; well combining economic growth and social progress; material and spiritual life; meeting immediate needs and looking after long-term interests; individuals and groups and social communities" ${ }^{1}$.

At the $8^{\text {th }}$ Congress (1996), our Party asserted our country's industrialization and modernization cause was a profoundly revolutionary developmental process in all fields of social life, not by any supernatural force, but the cause of the general public as a decisive resource. This fundamental, great and decisive resource had to contain increasingly high intellectual and ethical contents to possibly meet such a great industrialization and modernization cause: "Improving people's awareness, fostering and promoting great resources of the Vietnamese people are the decisive factors for the victory of industrialization and modernization" ${ }^{2}$. In the 2nd Central Executive Committee of term VIII (December 1996) resolution on the strategic orientations for education and

${ }^{1}$ Communist Party of Vietnam: Documents of the VIII National Congress of Delagates, National Politics Publishing House, Hanoi. 1996, p. 87.

${ }^{2}$ Communist Party of Vietnam: Platform for national construction during transition to socialism, National Politics Publishing House, Hanoi. 1991, p. 13. training development during industrialization and modernization and the missions until year 2000, it was indicated: "Human resource promotion is considered as a basic factor for rapid and sustainable development" ${ }^{3}$.

At the 10th Congress, our Party determined that it was required to focus on comprehensively renovating education and training, ameliorating the Vietnamese education to develop high-quality human resources. In the Summary report on a number of theoretical and practical issues over 20 years of renovation (1986 - 2006), our Party further confirmed: "Humans are the most invaluable asset, human development is both a motivation and a goal of the revolution and national renovation cause; attaching the human factor to humanity in order to help humans to develop comprehensively and live in a fair and compassionate society and healthy social relationships. Humans and human development are centered in socioeconomic strategies with expanded opportunities and improved conditions for human development" 4 .

At the $12^{\text {th }}$ Congress, our Party acknowledged: "Performing the human construction task to meet the industrialization, modernization and international integration period requirements brings an important transformation: attaching culture and human construction to country construction and development; attaching cultural environment construction to human construction; initially forming new human values with dignities of social responsibility, civic consciousness, democracy, initiative, creativity, aspiration to rise" ${ }^{5}$.

Inheriting and developing the core human issue contents in the Socialist Republic of Vietnam country construction and defence cause, the $8^{\text {th }}$ Party Congress outlined and set out the specific goals and tasks of comprehensive Vietnamese people construction and development to meet the country's sustainable socio-economic development requirements. The $8^{\text {th }}$ Party Congress specified the guiding ideology, main tasks and directions for Vietnamese people construction in

\footnotetext{
${ }^{3}$ Communist Party of Vietnam: Documents of the 2nd Conference of the Central Executive Committee of term 8, National Politics Publishing House, Hanoi.1997, p. 85.

${ }^{4}$ Communist Party of Vietnam (2005): Summary report on some theoretical and practical issues over 20 years of renovation 1986 2006, Hanoi, p.78-79.

${ }^{5}$ Communist Party of Vietnam (2016), Sđd, p.123.
} 
new conditions, especially human resource development before the fourth industrial revolution impact and in the context of socialist-oriented market economy and international integration. This was basically shown through: (i), emphasizing humans as a center of development and steadfastly developing the Vietnamese people comprehensively; "considering humans as the center, the most important subject and resource and the goal of development; taking Vietnamese culture and people values as the foundation, important internal strength for sustainable development" ${ }^{6}$ (ii), synchronizing the mechanisms and policies, and appreciating education and science to facilitate comprehensive human development; "Vietnamese people construction for comprehensive development, close and harmonious attachment of traditional and modern values" ${ }^{7}$ (iii), paying attention to, caring for and ensuring human rights, citizenship and developing high-quality human resources to meet the country construction and defense cause requirements; "Strengthening and developing human resources, especially high-quality human resources, to meet the requirements of the Fourth Industrial Revolution and international integration. Developing a team of leading experts and scientists; focusing on technical, digital, technology management, management, corporate governance; social management human resource teams and arranging life and caring for people" ${ }^{8}$

It can be said the above developments and changes are theoretical additions and concretized into specific tasks, solutions and orientations in directing practical activities of national socio-economic development in the past and in the future.

\subsection{Raised issues and fundamental challenges for Vietnamese people development in practice}

In the history of philosophy, there have appeared many different views about humans and human essence. On the basis of the materialist conception of history, C. Marx has given a complete conception of human as a socio-biological entity. Through this structure, C. Marx has clarified the relationship between man - nature - society. According to C. Marx, labor has decided human formation, marking the transformation from animals to humans. During labor, humans have built their material and spiritual cultural world, and also from labor, humans have formed their social essence such as language, thinking, communication, conception, value orientation, worldview, etc. Human essence has not been "inherent abstraction of a separate individual" as often thought, but of historicity - specificity. It has been a combination of the natural and social aspects, and the human "realistic basis" has been "the sum total of productive forces, capitals and social forms of communication which each individual and each generation

\footnotetext{
${ }^{6}$ Communist Party of Vietnam (2021), Documents of the $8^{\text {th }}$ National Congress, National Politics - Truth Publishing House, volume 1, p. 215 - 216

${ }^{7}$ Communist Party of Vietnam (2021), Documents of the $8^{\text {th }}$ National Congress, National Politics - Truth Publishing House, volume 1, p. 47

${ }^{8}$ Communist Party of Vietnam (2021), Documents of the $8^{\text {th }}$ National Congress, National Politics - Truth Publishing House, volume 1, p. 231
}

finds available" 9 . Human reality - "living individual humans manifest their objective existence in their practical activities: "Humans are abstract beings lurking somewhere outside the world. Humans are the human world, the state, and the society" ${ }^{10}$, therefore, "human essence is not inherent abstraction of a separate individual. In its reality, human essence is the ensemble of social relations" ${ }^{11}$. C. Marx's point of view has been a revolutionary turning point in the concepts of humans, human essence and human position and role during mankind development. At the same time, his point of view has also shown that all human productive labor activities have not been beyond the purpose of creating the entire material and spiritual culture. In the same sense, with their revolutionary activities, humans have marked new history pages for themselves in accordance with their needs and goals during their development. Along with considering human as a socio-biological entity and as a personality, C. Marx has also clarified the human position and role in history. It can be said that his views on humans and human liberation have great theoretical and practical values, becoming a theoretical basis for many scientific disciplines as well as for our Party in solutions to cultural, social and human issues in the current period.

To measure human development achievements, the United Nations development program has introduced a Human Development Index (HDI) calculation method since 1990. This is a composite index that reflects the levels of human development and mankind's common aspiration achievement such as high standards of living, high education, good health, and healthy community culture and society development, etc. In the recent period, the new concept of human development also includes many aspects:

Firstly, the goal of development is emphasized for humans, for sustainable improvement of human's quality of life.

Secondly, human development must be done by humans themselves.

Thirdly, the new conception of human development is based on a holistic approach.

Fourthly, it is to make a clear distinction between the concept of human development and human resource development.

Globalization and knowledge economy, on the one hand, generate great development possibilities and opportunities for the peoples and countries in general and human development in particular. In such a context, human development in the current period has the following basic challenges:

Firstly, human development is going along with human morality decline.

${ }^{9}$ C. Marx and Ph. Engels: Complete Volume, National Politics Publishing House, Hanoi, 1995, volume 3, p. 55.

${ }^{10}$ C. Marx and Ph. Engels: Complete Volume, Sđd, volume 3, p.569.

${ }^{11}$ C. Marx and Ph. Engels: Complete Volume, Sđd, volume 3, p.11. 
While scientific and technological advances have helped humans to make a new step forward in creating material wealth, the cultural and moral progress has not been commensurate.

Secondly, human development is associated with adaptation to networking space and time.

Science and technology development has brought many consequences but made humans quickly adapt in the competition-for-survival space. The concept of time - space has practically been almost transformed. They have been miraculous steps that have forced humans to adjust and change both their communication and behavior manners and assessment standards of morality, personality, lifestyle and working capacity.

In the recent period, we have seen the human role and motivation in socio-economic development, there have been many paticular policies to exploit this resource more effectively. Our Party and State have repeatedly emphasized the important role of human resources. However, in the new context of current Vietnamese practices, human development poses the following basic problems:

Firstly, there are still weaknesses both in human exploitation and use and in human development. The concrete manifestations are: education, training and the whole society have not successfully completed human development related to intellectual sustainability and physical and personality improvement for the young generation which are the two most important aspects in sustainable human development.

Secondly, generating jobs for workers, raising standards of living, ensuring security and safety of citizens in a stable and healthy environment with criteria of discipline, order, rules and laws present many shortcomings. According to C. Marx, this is the premise for the actual existence of humans.

Thirdly, the foundation is family life but family culture education has not been properly cared for and focused on. This is one of the major obstacles to human personality formation and social development.

\subsection{Basic solutions}

It is meeting the human resources requirements in the new context of the globalization and international integration trend, especially under the increasingly intensive and extensive impact of the fourth industrial revolution. Our Party affirms "There are plans, mechanisms and solutions to properly handle the relations between preservation and promotion of national cultural, historical and traditional values in human construction and socio-economic development" ${ }^{12}$, humans are both the goal and the motivation of socio-economic development; and they must have knowledge and morality simultaneously. Therefore, the core issue is to implement the strategies of human resource

\footnotetext{
${ }^{12}$ Communist Party of Vietnam (2021), Documents of the $8^{\text {th }}$ National Congress, National Politics - Truth Publishing House, volume 1, p. 145
}

education and training, both physically and mentally comprehensive human development. The education and training task is to help humans reach the values suitable to cultural characteristics and new requirements for the Vietnamese people to carry out our country's renovation, especially in the context of the increasingly intensive and extensive impact of the fourth industrial revolution and the current trend of international integration and knowledge economy development. The basic solutions to concentrate on will be:

Firstly, continuing to review and promulgate legal normative documents, building a legal basis to release all social potentials, taking care of and developing humans. Renovating education mechanism and methods of personality, ideology, political theory and revolutionary morality appropriate for each subject right from his/her preschool level. Studying and seeking value- and human right-based approaches to include and integrate them into political- legal approaches in the 10-year socio-economic development strategy from 2021-2030 in accordance with the socialist law state institution in order to promptly record, protect and ensure newly arising rights such as the network information security and safety right, on-internet platform trading and payment right, online religious and cultural education and activity right, privacy, especially on social media, physical safety right, personal information right and other relevant rights.

Secondly, there are feasible and practical policies to attract all human resources to participate in our country construction and development. Paying attention to and promoting the great national unity bloc, arousing potentials and promoting the Vietnamese people factor abroad, especially talented individuals and enterprises with material, spiritual and talent contribution to our country construction cause. Defining great national unity as a long-term strategy in the revolutionary cause, regularly improving mechanisms and policies, ensuring equality, respect, solidarity and harmonious settlement of relations among all ethnic groups. Developing a system of policies for each social class to maximize the entire people's potentials and strength in the innovation and integration cause.

Thirdly, sustainable development goal implementation requires consistency and clear "human-centered" definition. The 2013 Constitution with a separate chapter on "Human rights, citizen's rights and obligations", law reform, institution and policy improvement has been consolidated with more than 100 human-right related laws and codes newly promulgated or amended or supplemented. In fact, the Party and State of Vietnam have taken so many specific measures to ensure our people's rights in the civil, political, economic, socio-cultural fields, respect and ensure human rights in practice, and beautiful natural environment, stable socio-political conditions, unique culture, and friendly people.

\section{Conclusion}

The world's movement and development is objective, the arguments about humans, human development and human rights in Marxism-Leninism surpassed by reality or required 
to be supplemented for improvement are inevitable. Studying and summarizing the Marxist-Leninist theory on humans and human rights are always one of the urgent issues in the current period.

\section{References}

[1] Ban Chỉ đạo tổng kết lý luận Trung ương: Báo cáo tổng kết một số vấn đề lý luận - thực tiễn qua 30 năm đồi mới (1986-2016), Nxb Chính trị quốc gia, Hà Nội, 2015. (Central Theoretical Summary Steering Committee: Summary report on a number of theoretical and practical issues over 30 years of renovation (1986-2016), National Politics Publishing House, Hanoi, 2015.)

[2] C. Mác và Ph.Ăngghen (1995), Toàn tập, tập 3, Nxb Chính trị quốc gia, Hà Nội. (C. Marx and Ph. Engels (1995), Complete Volume, volume 3, National Politics Publishing House, Hanoi.)

[3] Đảng Cộng sản Việt Nam (1991), Cương lĩnh xây dựng đất nước trong thời kỳ quá độ lên chủ nghĩa xã hội. Nxb Sự thật, Hà Nội. (Communist Party of Vietnam (1991), Platform for country construction during transition to socialism. Truth Publishing House, Hanoi.)

[4] Đảng Cộng sản Việt Nam (1996), Văn kiện Đại hội đại biểu toàn quốc lần thứ VIII, Nxb. Chính trị quốc gia, Hà Nội. (Communist Party of Vietnam (1996), Documents of the VIII National Congress of Delegates, National Politics Publishing House, Hanoi.)

[5] Đảng Cộng sản Việt Nam (1997), Văn kiện Hội nghị lần thứ 2 Ban Chấp hành Trung ương khóa VIII, Nxb. Chính trị quốc gia, Hà Nội. (Communist Party of Vietnam (1997), Documents of the 2nd Conference of the Central Executive Committee of term VIII, National Politics Publishing House, Hanoi.)

[6] Đảng Cộng sản Việt Nam (2005), Báo cáo tổng kết một số vấn đề lý luận - thực tiễn qua 20 năm đổi mới 1986 2006, Nxb. Chính trị quốc gia, Hà Nội. (Communist Party of Vietnam (2005), Summary report on a number of theoretical and practical issues over 20 years of renovation from 1986 - 2006, National Politics Publishing House, Hanoi.)

[7] Đảng Cộng sản Việt Nam (2006), Văn kiện Đại hội đại biểu toàn quốc lần thứ $\mathrm{X}, \mathrm{Nxb}$ Chính trị Quốc gia, Hà Nội. (Communist Party of Vietnam (2006), Documents of the X National Congress of Delegates, National Politics Publishing House, Hanoi.)

[8] Đảng Cộng sản Việt Nam (2021), Văn kiện đại hội toàn quốc lần thứ XIII, Nxb CTQGST, tập 1. (Communist Party of Vietnam (2021), Documents of the $8^{\text {th }}$ National Congress, National Politics - Truth Publishing House, volume 1.)

[9] Phạm Minh Hạc (2001) (Chủ biên), Về phát triển toàn diện con người thời kỳ công nghiệp hóa, hiện đại hóa, Nxb Chính trị quốc gia, Hà Nội. (Pham Minh Hac (2001) (Editor), On comprehensive human development during industrialization and modernization, National Politics Publishing House, Hanoi.) 